ISSN 1392-3196 / e-ISSN 2335-8947

Zemdirbyste-Agriculture, vol. 103, No. 2 (2016), p. 183-192

DOI 10.13080/z-a.2016.103.024

\title{
Physical and chemical properties of soybean seeds determine their susceptibility to mechanical damage
}

\author{
Piotr KUŹNIAR ${ }^{1}$, Ewa SZPUNAR-KROK ${ }^{1}$, Pavol FINDURA ${ }^{2}$, Jan BUCZEK ${ }^{1}$, \\ Dorota BOBRECKA-JAMRO ${ }^{1}$ \\ ${ }^{1}$ University of Rzeszow \\ Zelwerowicza 4, 35-601 Rzeszów, Poland \\ E-mail: pkuzniar@ur.edu.pl \\ ${ }^{2}$ Slovak University of Agriculture in Nitra \\ Andreja Hlinku 2, 94976 Nitra, Slovakia
}

\begin{abstract}
The research was carried out to determine the influence of the chemical composition and moisture content in seeds from selected soybean cultivars on their mechanical properties. The individual seeds were investigated at five moisture contents in the conditions of quasi-static loads with the use of a Zwick universal testing machine. Mechanical properties of the soybean seeds from the analyzed cultivars depended on their chemical composition and moisture content. The seeds of the cv. 'Herta PZO' ruptured when the significantly smallest amount of the rupture force $(105.6 \mathrm{~N})$ was applied and were most prone to deformation $(29.2 \%)$. The seeds of the cv. KS-40 were significantly less prone to deformation $(16.7 \%)$ and ruptured with the smallest amount of energy $(71.5 \mathrm{~mJ})$ applied. The cv. 'Petrina' required the significantly highest amount of force $(140.6 \mathrm{~N})$ necessary for seed rupture, while the significantly highest modulus of elasticity $(1721 \mathrm{MPa})$ was observed in the cv. SP-16. The cv. 'Aligator' required application of the significantly highest amount of energy $(142.7 \mathrm{~mJ})$. An increase in the moisture content in seeds caused a significant decrease in the rupture force and modulus and an increase in deformation and energy. Soybean seeds with higher protein and ash content ruptured when higher force was applied and were characterised by a higher modulus of elasticity, smaller extent of deformation and lower energy, being therefore more resistant to damage. Soybean seeds containing more fat and fibre were more prone to damage. Together with the increase in the moisture content (7-19\%), we observed a decrease in the impact of the chemical components analyzed on the rupture force and the modulus of elasticity. At the same time we observed an increase in the influence of the tested components on deformation and energy.
\end{abstract}

Key words: chemical composition, mechanical properties, moisture content.

\section{Introduction}

Soybean (Glycine max (L.) Merrill) is a particularly good source of protein $(35-42 \%)$ and fat (16-27\%). This makes the soybean one of the most valuable and most commonly cultivated crops (Kumar et al., 2006). The soybean shares the flaw of many plants from the Fabaceae family, namely it is prone to mechanical damage occurring during threshing, cleaning, drying, transportation, storage and processing. Knowledge of the physical properties of soybean seeds is therefore particularly important for the optimization of harvesting, drying and storing processes, as it translates into minimization of losses and mechanical damage (Rybiński et al., 2009).

Unlike cereal grains, soybean seeds have two cotyledons between which a gap may be formed if the water content is low. This leads to an increased susceptibility of the seeds to damage like, for example, breaking in half (Shahbazi et al., 2011 a; Dobrzański, Stępniewski, 2013). The moisture content in seeds strongly influences the occurrence of mechanical damage, affecting elasticity and resistance in both cotyledons and the seed coat (Sosnowski, Kuźniar, 1999; Shao et al., 2007; Szwed, Łukaszuk, 2007; Shahbazi et al., 2011 a; b). Optimum moisture content at which the mechanical damage of seeds determined in the conditions of dynamic loads was minimum (Sosnowski, Kuźniar, 1999) and germination percentage was maximum (Divsalar, Oskouei, 2011) is $13-15 \%$. This stems from a very complex seed structure (Moïse et al., 2005). The process of crushing is strongly influenced by soybean seed elasticity and viscosity. Seed elasticity plays an important role in the first stage of crushing, and its viscosity - in the subsequent stages (Dobrzański, Stępniewski, 2013). The occurrence of damage also depends on the size and shape of seeds as well as seed coat thickness and chemical composition (Capeleti et al., 2005; Rybiński et al., 2013). Karaj and Müller (2010) and Dobrzański and Stępniewski (2013) demonstrated that seed resistance to mechanical damage 
significantly decreases together with an increase in seed weight. A similar correlation was observed by Kuźniar et al. (2013) in the legume plants analyzed. Cultivars with heavier and thicker seeds were found to be less susceptible to mechanical damage. The increase in seed weight also resulted in the increase in resistance to damage, whereas the increase in seed thickness resulted in decreased deformation.

The aim of the study was to assess the influence of the chemical composition and moisture content in the seeds of the selected soybean cultivars on their mechanical properties.

\section{Material and methods}

Research material comprised seeds of seven cultivars and three lineages of soybean (Glycine max (L.) Merrill) cultivated in 2014 in the Podkarpacie region (Poland), on the premises of the Przecław Plant Variety Testing Station (alluvial soil, very good wheat complex, class II).

Total protein content was measured by the Kjeldahl method, calculated on the basis of total nitrogen content and 6.25 conversion factor, crude fat was determined by the Soxhlet method, crude fibre by the Henneberg-Stohmann method, and crude ash content was established by burning the material in $600^{\circ} \mathrm{C}$. The initial moisture content of the seeds was determined using ASAE standard S352.2 (2006) involving the oven-drying method. The samples were placed in an oven set at $103^{\circ} \mathrm{C}$ for $72 \mathrm{~h}$. The samples were cooled in a exsiccator, reweighed and the moisture content of the seeds calculated. The quantity of distilled water was calculated from the following equation (Kibar, Öztürk, 2008; Davies, Zibokere, 2011):

$$
W_{W}=W_{S} \frac{M_{f}-M_{i}}{100-M_{f}},
$$

where $W_{W}$ is distilled water weight $(\mathrm{g}), W_{S}-$ dry sample weight $(\mathrm{g}), M_{f}$ - final moisture content of sample (\%), $M_{i}$ - initial moisture content (\%).

Thereafter, seed samples of the desired moisture level were prepared by adding the calculated amount of distilled water and sealing in separate polythene bags. The seeds were kept in a refrigerator at a temperature of $5^{\circ} \mathrm{C}$ for one week to enable the moisture to distribute uniformly Razari et al. (2007). Prior to the experiment, the samples were taken out of the refrigeration and allowed to warm up to room temperature for four hours. The mechanical properties of seeds were investigated at five moisture contents: 7, 10, 13, 16 and $19 \%$ (optimum moisture content, two lower and two higher). The resistance of individual seeds to mechanical damage was determined in the conditions of quasi-static loads with the use of a Zwick universal testing machine, in accordance with the previously developed methodology (Kuźniar et al., 2013; Nasirahmadi et al., 2014).

The following parameters indicated the seed resistance to mechanical damage: maximum force $(\mathrm{N})$ resulting in seed rupture, maximum deformation $(\mathrm{mm})$ at the moment of rupture, modulus of elasticity $(\mathrm{MPa})$ and strain energy $(\mathrm{J})$ required to crush the seed. The obtained values were used to calculate relative deformation at a given rupture force, with the following formula (Altuntas, Yildiz, 2007):

$$
\varepsilon=\frac{D}{T} 100 \%,
$$

where $\varepsilon$ is relative deformation (\%), $D-$ maximum deformation ( $\mathrm{mm}), T$ - thickness of seed (mm).

Load was applied perpendicularly to the plane of cotyledon separation, with a constant velocity $v=$ $10 \mathrm{~mm} \mathrm{~min}^{-1}$. Sample size comprised 20 seeds per each treatment. Before the load was applied, the seeds were measured with respect to their weight ( $0.001 \mathrm{~g}$ tolerance), length, width and thickness ( $0.01 \mathrm{~mm}$ tolerance), and the sphericity $\varphi(\%)$ was calculated using the relationship described by Koocheki et al. (2007), Milani et al. (2007) and Sharma et al. (2011):

$$
\varphi=\frac{(L W T)^{\frac{1}{3}}}{L} 100 \%,
$$

where $\varphi$ is sphericity (\%), $L$ - length (mm), $W-$ width (mm), $T$ - thickness (mm).

Statistical analysis of the results was conducted using the software Statistica 10. Bivariate analysis of variance and the LSD significance test at $\alpha=0.05$ were performed.

\section{Results and discussion}

The soy cultivars analyzed differed significantly in terms of the seed length, width, thickness, roundness and weight (Table 1). Soybean 'Petrina' seeds were the widest $(7.03 \mathrm{~mm})$, the thickest $(6.15 \mathrm{~mm})$, the roundest $(92.53 \%)$ and the heaviest (209 $\mathrm{mg})$. The soybean 'Aligator' seeds were the longest $(7.93 \mathrm{~mm})$ and the least spherical. Soybean 'Augusta' seeds were the smallest, with seeds $7.25 \mathrm{~mm}$ in length, $6.43 \mathrm{~mm}$ in width, $5.13 \mathrm{~mm}$ in thickness and the $153 \mathrm{mg}$ in weight.

Both factors investigated, i.e. cultivar and moisture content, had a statistically significant effect on all the resistance parameters analyzed. Soybean 'Herta PZO' seeds (Table 2) were the most prone to damage, rupturing at the significantly lowest force of $105.6 \mathrm{~N}$ on average, and displayed the highest deformation (29.2\%). Cultivar KS-40 seeds were the significantly least prone to deformation $(16.8 \%)$ and ruptured when the lowest amount of energy $(71.5 \mathrm{~mJ})$ was applied. 'Petrina' seeds were the least susceptible to mechanical damage - they required the use of the significantly highest force $(140.6 \mathrm{~N})$. The significantly highest modulus of elasticity (1721 MPa) was observed in cv. SP-16 seeds, and the significantly highest energy $(142.7 \mathrm{~mJ})$ in 'Aligator' seeds.

The increase in moisture content from $7 \%$ to $19 \%$ was accompanied by the significant decrease in force (166.1 to $86.2 \mathrm{~N}$ ) necessary to destroy seeds (Table 3) and in modulus (4503 to $196 \mathrm{MPa}$ ) (Table 4) as well as the significant increase in deformity (4.9\% to $52.8 \%$ ) (Table 3 ) and energy (19.6 to $247.5 \mathrm{~mJ}$ ) (Table 4). 
Table 1. Seeds characteristics of the tested soybean cultivars

\begin{tabular}{|c|c|c|c|c|c|}
\hline \multirow{2}{*}{ Cultivar } & \multicolumn{3}{|c|}{ Seeds dimensions $\mathrm{mm}$} & \multirow{2}{*}{$\begin{array}{c}\text { Sphericity } \\
\%\end{array}$} & \multirow{2}{*}{$\begin{array}{c}\text { Mass } \\
\mathrm{mg}\end{array}$} \\
\hline & length & width & thickness & & \\
\hline Aldana & $7.81 \mathrm{~cd}(0.68)$ & $6.80 \mathrm{~cd}(0.46)$ & 5.55 bc $(0.43)$ & $85.13 \mathrm{a}(2.88)$ & 192 c (42) \\
\hline Aligator & $7.93 \mathrm{~d}(0.64)$ & $6.94 \mathrm{de}(0.37)$ & $5.61 \mathrm{c}(0.32)$ & $85.42 \mathrm{ab}(3.34)$ & $205 \mathrm{~d}(36)$ \\
\hline Amandine & $7.50 \mathrm{~b}(0.51)$ & $6.69 \mathrm{bc}(0.38)$ & $5.58 \mathrm{c}(0.44)$ & 87.28 c (3.04) & 185 bc (34) \\
\hline Augusta & $7.25 \mathrm{a}(0.73)$ & $6.43 \mathrm{a}(0.47)$ & $5.13 \mathrm{a}(0.42)$ & $85.87 \mathrm{ab}(4.72)$ & 153 a (39) \\
\hline Herta PZO & $7.61 \mathrm{bc}(0.68)$ & $6.88 \mathrm{~d}(0.49)$ & $5.79 \mathrm{~d}(0.52)$ & $88.45 \mathrm{~cd}(4.38)$ & 189 c (36) \\
\hline KS-40 & $7.49 \mathrm{~b}(0.46)$ & $6.92 \mathrm{~d}(0.37)$ & $5.77 \mathrm{~d}(0.28)$ & $89.34 \mathrm{~d}(2.26)$ & $197 \mathrm{~cd}(29)$ \\
\hline Mavka & $7.44 \mathrm{~b}(0.42)$ & 7.01 e $(0.41)$ & 6.02 ef $(0.43)$ & 91.38 e (3.71) & $204 \mathrm{~d}(33)$ \\
\hline Petrina & $7.39 \mathrm{ab}(0.52)$ & 7.03 e $(0.42)$ & $6.15 \mathrm{f}(0.47)$ & 92.53 e (3.00) & $209 \mathrm{~d}(38)$ \\
\hline SP-16 & $7.27 \mathrm{a}(0.44)$ & $6.62 \mathrm{~b}(0.32)$ & 5.98 e $(0.29)$ & 90.83 e $(2.84)$ & $193 \mathrm{~cd} \mathrm{(28)}$ \\
\hline SP-29 & $7.40 \mathrm{ab}(0.74)$ & $6.54 \mathrm{ab}(0.53)$ & $5.40 \mathrm{~b}(0.50)$ & $86.52 \mathrm{bc}(3.50)$ & $176 \mathrm{~b}(45)$ \\
\hline Average & $7.51(0.62)$ & $6.79(0.47)$ & $5.70(0.51)$ & $88.27(4.24)$ & $190(39)$ \\
\hline
\end{tabular}

Note. Mean values in columns marked with the same letter do not differ significantly at $\alpha=0.05$; standard deviation values in parentheses.

Table 2. Mean strength properties of seeds of the tested soybean cultivars

\begin{tabular}{ccccc}
\hline Cultivar & Force & $\begin{array}{c}\text { Deformation } \\
\%\end{array}$ & $\begin{array}{c}\text { Energy } \\
\mathrm{mJ}\end{array}$ & $\begin{array}{c}\text { Modulus } \\
\text { MPa }\end{array}$ \\
\hline Aldana & $118.1 \mathrm{ab}(28.0)$ & $24.2 \mathrm{~cd}(7.6)$ & $101.0 \mathrm{c}(33.2)$ & $1424 \mathrm{c}(1026)$ \\
Aligator & $137.1 \mathrm{c}(36.8)$ & $28.3 \mathrm{~d}(12.7)$ & $142.7 \mathrm{e}(76.4)$ & $1119 \mathrm{a}(850)$ \\
Amandine & $132.3 \mathrm{c}(49.1)$ & $23.0 \mathrm{c}(12.6)$ & $102.3 \mathrm{c}(70.0)$ & $1593 \mathrm{de}(1163)$ \\
Augusta & $112.2 \mathrm{ab}(35.8)$ & $23.7 \mathrm{c}(10.8)$ & $76.5 \mathrm{a} \mathrm{(39.7)}$ & $1268 \mathrm{~b}(896)$ \\
Herta PZO & $105.6 \mathrm{a}(46.4)$ & $29.2 \mathrm{~d}(8.4)$ & $125.9 \mathrm{de}(40.8)$ & $1206 \mathrm{a}(929)$ \\
KS-40 & $136.4 \mathrm{bc}(40.7)$ & $16.8 \mathrm{a}(7.7)$ & $71.5 \mathrm{a}(33.6)$ & $1644 \mathrm{de} \mathrm{(1143)}$ \\
Mavka & $127.0 \mathrm{~b}(42.7)$ & $22.3 \mathrm{bc}(9.4)$ & $99.6 \mathrm{bc}(61.5)$ & $1387 \mathrm{bc}(964)$ \\
Petrina & $140.6 \mathrm{c}(43.8)$ & $23.5 \mathrm{bc}(11.1)$ & $107.8 \mathrm{~cd}(88.9)$ & $1376 \mathrm{bc}(1097)$ \\
SP-16 & $124.2 \mathrm{~b}(41.6)$ & $20.1 \mathrm{~b}(8.9)$ & $83.7 \mathrm{ab}(50.4)$ & $1721 \mathrm{e}(1384)$ \\
SP-29 & $115.0 \mathrm{ab}(56.1)$ & $28.1 \mathrm{~d}(13.2)$ & $139.0 \mathrm{de}(90.1)$ & $1478 \mathrm{~cd}(1162)$ \\
\hline Average & $124.8(44.7)$ & $23.9(10.9)$ & $105.0(65.2)$ & $1422(1097)$ \\
\hline
\end{tabular}

Note. Mean values in columns marked with the same letter do not differ significantly at $\alpha=0.05$; standard deviation values in parentheses.

Table 3. Destructive force and deformation of soybean seeds of different moisture content

\begin{tabular}{|c|c|c|c|c|c|}
\hline \multirow{2}{*}{ Cultivar } & \multicolumn{5}{|c|}{ Moisture content $\%$} \\
\hline & 7 & 10 & 13 & 16 & 19 \\
\hline \multicolumn{6}{|c|}{ Force N } \\
\hline Aldana & $149.2 \mathrm{~b}(35.3)$ & $130.8 \mathrm{~b} \mathrm{(20.7)}$ & $118.4 \mathrm{~b}(17.3)$ & $103.1 \mathrm{bc}(11.2)$ & 88.8 bc (6.6) \\
\hline Aligator & $173.0 \mathrm{~cd}(37.7)$ & 151.5 c (15.4) & $139.0 \mathrm{~cd}(45.3)$ & $118.1 \mathrm{c}(20.3)$ & 103.7 c (8.3) \\
\hline Amandine & 185.6 e (32.3) & $157.7 \mathrm{~cd}(17.9)$ & 129.9 c 0.1$)$ & 101.2 b (32.7) & 87.0 bc (18.1) \\
\hline Augusta & $138.1 \mathrm{a}(45.1)$ & $126.4 \mathrm{ab}(22.8)$ & $110.3 \mathrm{ab}(33.9)$ & $98.1 \mathrm{ab}(18.9)$ & 87.9 bc (9.6) \\
\hline Herta PZO & 131.3 a (50.1) & 119.2 a (49.6) & $101.2 \mathrm{a}(38.4)$ & $93.1 \mathrm{ab}(31.9)$ & $83.0 \mathrm{~b}(31.5)$ \\
\hline KS-40 & $182.1 \mathrm{de}(43.3)$ & $164.0 \mathrm{~d}(23.4)$ & 131.0 c (26.5) & 110.9 bc (15.8) & 93.8 bc (8.5) \\
\hline Mavka & 169.3 c (25.0) & 149.7 c (25.7) & $123.0 \mathrm{bc}(56.2)$ & $102.4 \mathrm{~b}(33.6)$ & $90.7 \mathrm{bc}(24.6)$ \\
\hline Petrina & $184.1 \mathrm{de}(37.7)$ & $162.4 \mathrm{~d}(12.0)$ & $140.6 \mathrm{~cd}(55.8)$ & 118.8 c (19.5) & 97.0 c (6.2) \\
\hline SP-16 & $172.6 \mathrm{c}(44.4)$ & $140.7 \mathrm{bc}(20.0)$ & $120.8 \mathrm{bc}(39.1)$ & 107.9 bc (19.4) & $79.0 \mathrm{~b}(8.7)$ \\
\hline SP-29 & $175.9 \mathrm{~cd}(47.4)$ & $141.1 \mathrm{bc}(21.1)$ & $119.3 \mathrm{~b}(74.8)$ & $88.1 \mathrm{a}(36.6)$ & $50.8 \mathrm{a}(16.3)$ \\
\hline Average & $166.1^{5}(45.2)$ & $144.4^{4}(27.3)$ & $123.3^{3}(50.1)$ & $104.2^{2}(2.3)$ & $86.2^{1}(16.5)$ \\
\hline \multicolumn{6}{|c|}{ Deformation $\%$} \\
\hline Aldana & $4.9 \mathrm{a}(0.6)$ & $8.9 \mathrm{ab}(1.3)$ & $19.6 \mathrm{ab}(4.4)$ & $35.5 \mathrm{c}(8.0)$ & 52.2 c (12.9) \\
\hline Aligator & 5.6 a (1.6) & $10.6 \mathrm{~b}(2.7)$ & $22.9 \mathrm{~b}(13.5)$ & $39.2 \mathrm{~cd}(23.1)$ & $63.3 \mathrm{~d}(31.0)$ \\
\hline Amandine & 4.6 a $(0.4)$ & $8.4 \mathrm{ab}(1.1)$ & $18.8 \mathrm{ab}(12.6)$ & $32.6 \mathrm{~b}(21.9)$ & 50.5 c (37.2) \\
\hline Augusta & $5.4 \mathrm{a}(1.2)$ & $9.5 \mathrm{ab}(1.8)$ & $19.8 \mathrm{ab}(10.5)$ & 33.8 bc (17.9) & $49.7 \mathrm{bc}(28.9)$ \\
\hline Herta PZO & $3.8 \mathrm{a}(1.3)$ & $8.0 \mathrm{ab}(3.9)$ & $21.1 \mathrm{~b}(7.8)$ & $41.5 \mathrm{~d}(15.3)$ & 71.5 e $(29.0)$ \\
\hline KS-40 & $5.4 \mathrm{a}(0.8)$ & $8.2 \mathrm{ab}(1.6)$ & 15.6 a $(5.5)$ & 20.8 a $(7.4)$ & $33.8 \mathrm{a}(13.2)$ \\
\hline Mavka & $4.6 \mathrm{a}(0.5)$ & $8.1 \mathrm{ab}(2.5)$ & $18.1 \mathrm{ab}(7.5)$ & $31.1 \mathrm{~b}(12.8)$ & $49.8 \mathrm{bc}(22.5)$ \\
\hline Petrina & $5.2 \mathrm{a}(0.9)$ & $9.2 \mathrm{ab}(1.4)$ & $19.5 \mathrm{ab}(13.9)$ & $33.7 \mathrm{~b}(24.0)$ & 50.1 c $(29.3)$ \\
\hline SP-16 & $4.6 \mathrm{a}(0.8)$ & 7.6 a (2.3) & $16.5 \mathrm{a}(8.0)$ & $27.6 \mathrm{ab}(13.4)$ & $44.2 \mathrm{~b}(23.5)$ \\
\hline SP-29 & $5.3 \mathrm{a}(1.0)$ & $10.1 \mathrm{ab}(2.5)$ & $22.5 \mathrm{~b}(13.0)$ & $40.3 \mathrm{~d}(25.1)$ & $62.5 \mathrm{~d}(32.7)$ \\
\hline Average & $4.9^{1}(1.0)$ & $8.9^{2}(2.4)$ & $19.4^{3}(11.0)$ & $33.61^{4}(19.0)$ & $52.8^{5}(32.8)$ \\
\hline
\end{tabular}

Note. Mean values in columns marked with the same letter, and in rows marked with the same numerals do not differ significantly at $\alpha=0.05$; standard deviation values in parentheses. 
Table 4. Strain energy and modulus of elasticity of soybean seeds of different moisture content

\begin{tabular}{|c|c|c|c|c|c|}
\hline \multirow{2}{*}{ Cultivar } & \multicolumn{5}{|c|}{ Moisture content \% } \\
\hline & 7 & 10 & 13 & 16 & 19 \\
\hline \multicolumn{6}{|c|}{ Energy $\mathrm{mJ}$} \\
\hline Aligator & $17.3 \mathrm{a}(6.4)$ & $40.5 \mathrm{ab}(13.0)$ & 80.7 b (26.9) & $132.6 \mathrm{c}(39.8)$ & 233.8 c (54.7) \\
\hline Amandine & $25.2 \mathrm{a}(10.7)$ & 56.6 c (15.5) & $111.9 \mathrm{~d}(67.2)$ & 179.0 e (111.1) & 341.1 e (164.7) \\
\hline Augusta & 19.6 a (7.0) & $43.1 \mathrm{ab}(11.2)$ & $82.5 \mathrm{~b}(65.8)$ & 134.7 c (96.8) & 231.7 c (129.4) \\
\hline Herta PZO & $16.4 \mathrm{a}(7.9)$ & $32.5 \mathrm{a}(14.7)$ & $60.6 \mathrm{a}(40.0)$ & 98.6 a (58.6) & 174.4 b (80.6) \\
\hline KS-40 & $12.6 \mathrm{a}(9.1)$ & $34.5 \mathrm{a}(21.5)$ & 85.4 bc (45.7) & $154.5 \mathrm{~d}(74.4)$ & 342.3 e (128.3) \\
\hline Mavka & $22.7 \mathrm{a}(8.3)$ & $41.3 \mathrm{a}(13.3)$ & 65.9 a (26.8) & $96.1 \mathrm{a}(35.2)$ & 131.7 a (37.5) \\
\hline Petrina & $18.1 \mathrm{a}(5.8)$ & $42.4 \mathrm{ab}(20.3)$ & 79.7 b (48.9) & 117.7 b (64.9) & $239.9 \mathrm{~cd}(102.9)$ \\
\hline SP-16 & 23.9 a (9.5) & $51.0 \mathrm{bc}(8.0)$ & $93.1 \mathrm{c}(61.1)$ & $123.4 \mathrm{bc}(72.8)$ & $247.9 \mathrm{~d}(113.8)$ \\
\hline SP-29 & 18.0 a (8.9) & 37.0 a (18.9) & $69.8 \mathrm{ab}(50.3)$ & $100.3 \mathrm{ab}(65.1)$ & 193.3 b (97.6) \\
\hline Aligator & $21.9 \mathrm{a}(10.3)$ & $52.7 \mathrm{bc}(14.1)$ & $107.0 \mathrm{~cd}(77.9)$ & $174.4 \mathrm{e}(103.7)$ & 339.0 e (217.3) \\
\hline Average & $19.6^{1}(9.0)$ & $43.2^{2}(19.0)$ & $83.6^{3}(51.2)$ & $131.1^{4}(86.4)$ & $247.5^{5}(126.8)$ \\
\hline \multicolumn{6}{|c|}{ Modulus MPa } \\
\hline Aldana & 4396 c (784) & $1593 \mathrm{~cd}(203)$ & $601 \mathrm{ab}(62)$ & $341 \mathrm{ab}(42)$ & 190 a (21) \\
\hline Aligator & 3409 a (574) & $1261 \mathrm{ab}(307)$ & $508 \mathrm{ab}(92)$ & $242 \mathrm{ab}(53)$ & 177 a (35) \\
\hline Amandine & 6072 e (421) & 1193 a (265) & 422 a (58) & 184 a (30) & 95 a (14) \\
\hline Augusta & 3857 b (606) & $1302 \mathrm{ab}(310)$ & $622 \mathrm{ab}(104)$ & $346 \mathrm{ab}(69)$ & 213 a (38) \\
\hline Herta PZO & 4018 b (675) & 1125 a (402) & 458 a (154) & $305 \mathrm{ab}(93)$ & $125 \mathrm{a}(45)$ \\
\hline KS-40 & $4771 \mathrm{~d}(512)$ & $1851 \mathrm{~d}(432)$ & 951 c (96) & $381 \mathrm{ab}(46)$ & 269 a (29) \\
\hline Mavka & 4338 c (312) & $1571 \mathrm{~cd} \mathrm{(318)}$ & $598 \mathrm{ab}(84)$ & $230 \mathrm{ab}(39)$ & $200 \mathrm{a}(30)$ \\
\hline Petrina & 3906 b (278) & $1471 \mathrm{bc}(246)$ & $847 \mathrm{bc}(83)$ & 387 b (45) & 268 a (28) \\
\hline SP-16 & 5329 de (527) & 1779 d (295) & 749 bc (69) & 496 b (55) & 253 a (25) \\
\hline SP-29 & $4934 \mathrm{~d}(820)$ & $1521 \mathrm{bc}(323)$ & 417 a (58) & $346 \mathrm{ab}(57)$ & $173 \mathrm{a}(26)$ \\
\hline Average & $4503^{4}(734)$ & $1467^{3}(353)$ & $617^{2}(111)$ & $326^{1}(60)$ & $196^{1}(38)$ \\
\hline
\end{tabular}

Note. Mean values in columns marked with the same letter, and in rows marked with the same numerals do not differ significantly at $\alpha=0.05$. Standard deviation values in parentheses.

The lower the seed modulus of elasticity, the higher its viscosity parameter and the lower its mechanical damage resistance to fractures occurring due to external forces (Chigarev, 2013).

The cultivars studied showed little diversity in deformation (Fig. 2) and energy (Fig. 4) for the lowest moisture (7\%). This diversity increased along with the increase in moisture, with the highest diversity reported at $19 \%$ moisture content. The reverse was found for modulus (Fig. 3), where the decrease in diversity among cultivars occurred as the moisture content increased. The relation between destructive force and moisture content is best described as a linear function (Fig. 1), and deformation (Fig. 2), energy (Fig. 4) and modulus (Fig. 3) as a power function. Similar correlations were described by Aghkhani et al. (2012) for Christmas Lima bean seeds, Kiani Deh Kiani et al. (2008) for red bean seeds and Kabutey et al. (2014) for Jatropha seeds. The aforementioned authors used the linear function to describe the correlation between moisture content and force as well as deformation, energy and modulus of elasticity. Łysiak and Laskowski (2007) on the other hand, reported a relation between deformation and moisture content on wheat grain in reflected as a power function. Altuntas and
Y1ldiz (2007) and Tavakoli et al. (2009) reported a relation between force and moisture content on soya seeds, as well as between energy and moisture content with a quadratic function. The influence of moisture content of soya seeds on energy and deformation presented by Altuntas and Yildiz (2007) has more a power function character than a quadratic function. Hebda and Frączek (2005), on the other hand, reported a relation between compressive energy in legume seeds (beans, peas and vetch) reflected as a power function, and for caryopses of wheat and rye the relation between moisture and energy was a more linear function.

Changes in the analyzed resistance parameters of the soybean seeds concurrent with the increase of moisture content were varied among the cultivars studied. The highest concurrent decrease in force (nearly 3.5fold) was observed in the cv. SP-29 and the lowest (1.57fold) in the 'Augusta'. The highest increase in resilience and energy occurred in the 'Herta PZO' (19-fold and 27fold, respectively), and the lowest in the cv. KS-40 (6.2fold and 5.8-fold, respectively). The highest decrease in modulus occurred in the 'Amandine' soybeans (64-fold) and the lowest in the 'Petrina' (14.6-fold). Protein content in the seeds of soybean cultivars studies was found to 


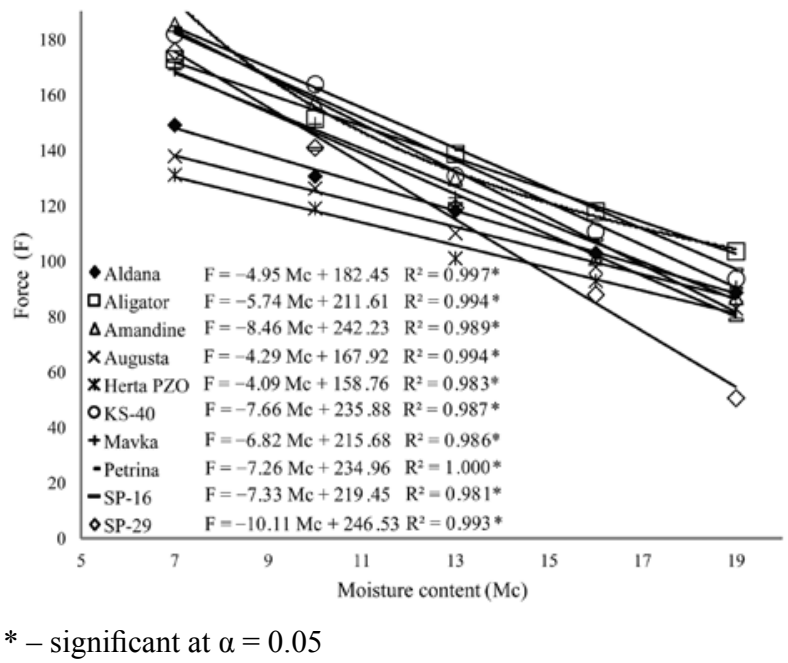

Figure 1. The relationship between destructive force $(\mathrm{N})$ and moisture content of seeds (\%) of the tested soybean cultivars

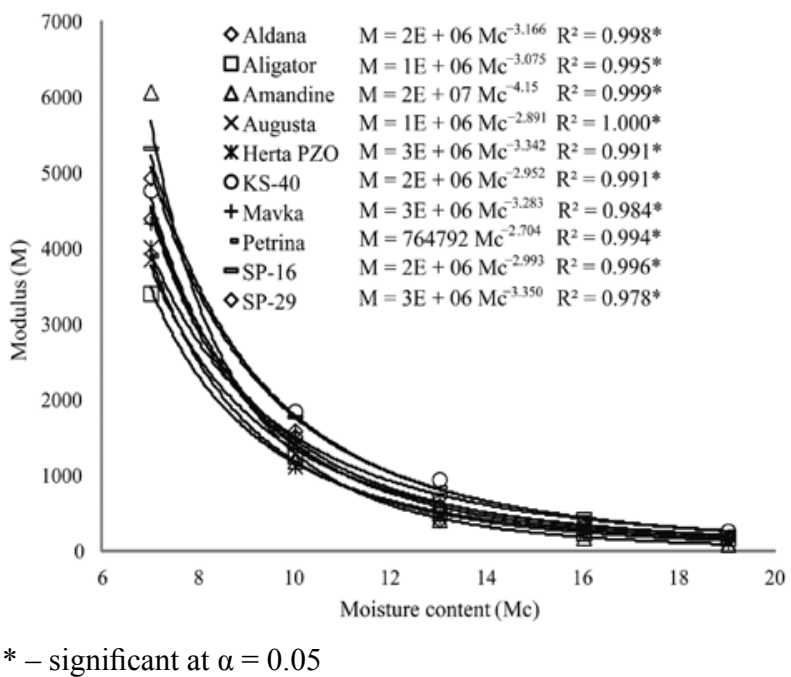

Figure 3. The relationship between modulus of elasticity $(\mathrm{MPa})$ and moisture content of seeds $(\%)$ of the tested soybean cultivars

be between $31.35 \%$ in 'Herta PZO' and $36.97 \%$ in 'Amandina', fat content between 17.93\% (cv. SP-16) and 21.93\% ('Aligator'), fibre between 7.03\% ('Petrina') and 8.78\% ('Augusta'), ash between 4.86\% ('Herta PZO') and $5.49 \%$ ('Petrina'). Variance analysis results indicate that the soy cultivars differed in terms of the average content of fat, fibre and ash (Table 5).

The influence of chemical composition of soybean seeds on their mechanical properties varied in the analysed cultivars and depended on their moisture content. Soybean seeds containing more protein and ash required more force to burst (Fig. 5) and were characterized by a higher seeming modulus of elasticity (Fig. 7), being more resistant to damage, and seeds with higher fibre content were more easily damaged. In contrast, the influence of fat content in seeds on destructive force was not significant at all moisture contents. The increase of seed moisture

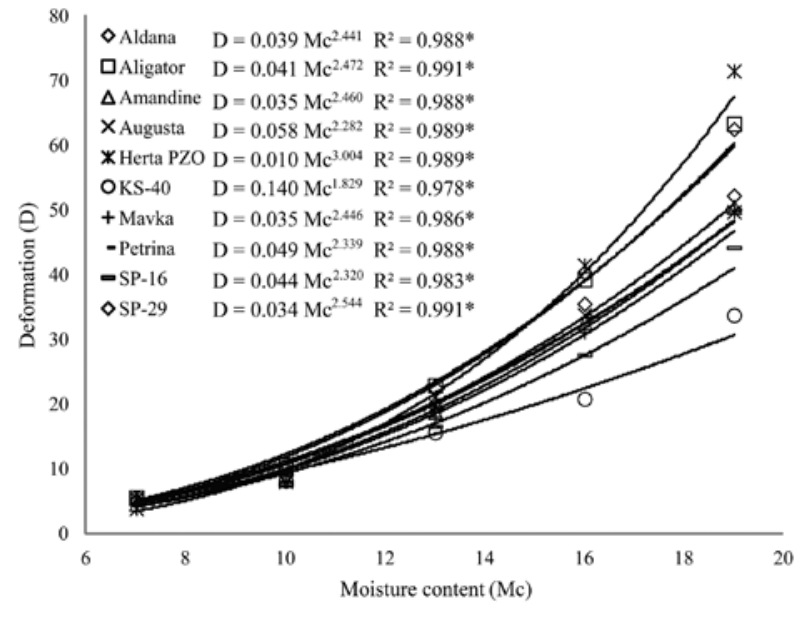

$*$ - significant at $\alpha=0.05$

Figure 2. The relationship between deformation (\%) and moisture content of seeds $(\%)$ of the tested soybean cultivars

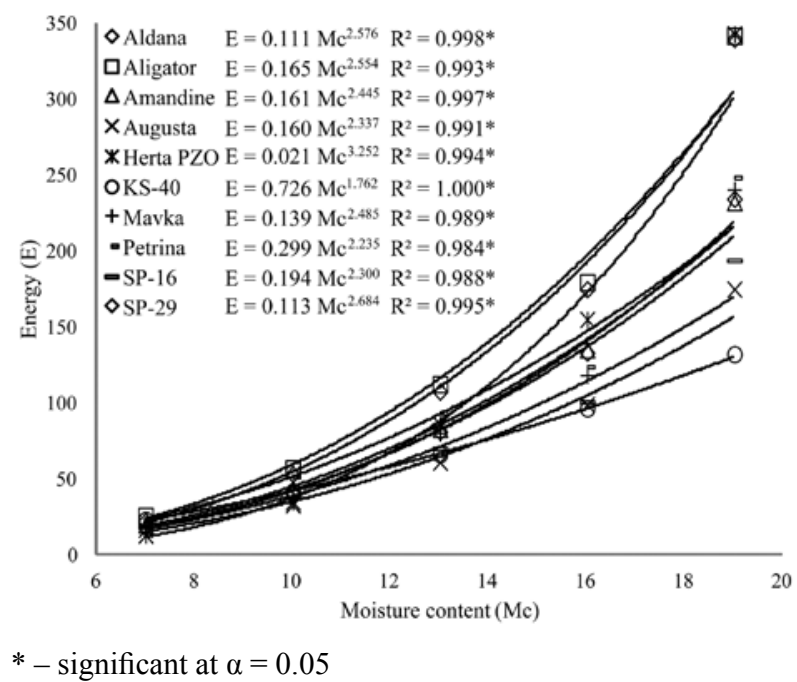

Figure 4. The relationship between destructive energy $(\mathrm{mJ})$ and moisture content of seeds (\%) of the tested soybean cultivars

(7-19\%) was correlated with the decrease in impact of analyzed chemical composition on destructive force. This is evidenced by a decreasing coefficient of determination $R^{2}$ and coefficient of slope of the line describing the relation between mechanical parameters and chemical composition of seeds from analyzed soybean cultivars.

Seeds with decreased protein, fibre and ash content and higher fat content required more energy to be destroyed (Fig. 8). The influence of these contents on energy was higher with increased moisture. Similarly, seeds with less protein and ash and more fat were more easily deformed (Fig. 6), especially with increased moisture. Higher fibre content in seeds with $7 \%$ to $13 \%$ moisture led to a slight decrease in deformity; in seeds with $16 \%$ to $19 \%$ moisture, it led to an increase in deformity. Rybiński et al. (2013) studied the influence of protein and fat content in seeds of four cultivars of 
Table 5. The chemical composition (\%) of seeds of the tested soybean cultivars

\begin{tabular}{ccccc}
\hline Cultivar & Total proteins & Fat & Dietary fibre & Ash \\
\hline Aldana & $35.21 \mathrm{a}(2.49)$ & $21.90 \mathrm{~d}(0.56)$ & $7.91 \mathrm{ab}(0.54)$ & $5.18 \mathrm{bc}(0.22)$ \\
Aligator & $33.91 \mathrm{a}(2.87)$ & $21.93 \mathrm{~d}(0.65)$ & $7.51 \mathrm{ab}(0.37)$ & $4.92 \mathrm{a}(0.20)$ \\
Amandine & $36.97 \mathrm{a}(1.95)$ & $21.34 \mathrm{~cd}(0.72)$ & $7.43 \mathrm{ab}(0.49)$ & $5.10 \mathrm{ab}(0.18)$ \\
Augusta & $35.37 \mathrm{a}(1.51)$ & $20.99 \mathrm{~cd}(0.69)$ & $8.78 \mathrm{c}(1.07)$ & $5.22 \mathrm{bc}(0.30)$ \\
Herta PZO & $31.35 \mathrm{a}(2.38)$ & $20.52 \mathrm{c}(0.78)$ & $8.72 \mathrm{c}(0.88)$ & $4.86 \mathrm{a}(0.15)$ \\
KS-40 & $35.59 \mathrm{a}(2.99)$ & $19.12 \mathrm{~b}(0.68)$ & $8.33 \mathrm{bc}(0.58)$ & $5.41 \mathrm{bc}(0.25)$ \\
Mavka & $33.70 \mathrm{a}(2.50)$ & $21.00 \mathrm{~cd}(0.92)$ & $7.86 \mathrm{ab}(0.33)$ & $5.09 \mathrm{a}(0.15)$ \\
Petrina & $35.33 \mathrm{a}(2.86)$ & $20.67 \mathrm{c}(1.12)$ & $7.03 \mathrm{a}(0.44)$ & $5.49 \mathrm{c}(0.15)$ \\
SP-16 & $36.33 \mathrm{a} \mathrm{(2.67)}$ & $17.93 \mathrm{a}(0.45)$ & $7.48 \mathrm{ab}(0.58)$ & $5.19 \mathrm{bc}(0.25)$ \\
SP-29 & $34.79 \mathrm{a}(2.96)$ & $20.89 \mathrm{~cd}(0.87)$ & $7.80 \mathrm{ab}(0.62)$ & $5.12 \mathrm{ab}(0.25)$ \\
\hline Average & $34.86(2.71)$ & $20.63(1.36)$ & $7.89(0.78)$ & $5.16(0.27)$ \\
\hline
\end{tabular}

Note. Mean values in columns marked with the same letter do not differ significantly at $\alpha=0.05$; standard deviation values in parentheses.

lupines, peas and grasspea on resistance to mechanical overload and reported the occurrence of similar adverse correlation between module and fat content.

The reported adverse correlation between modulus and protein content may have resulted from higher variety in protein content among studied cultivars as well as their moisture content of $13 \%$. The modulus of elasticity of soybeans seeds was positively correlated with the content of fat (Fig. 7), with the proviso that the strongest correlations were observed at moisture content $7 \%$ and $10 \%$, and the poor correlation at moisture content $16 \%$ and $19 \%$. This may mean that at even higher water contents in the soybean seeds the impact of fat content on the modulus of elasticity can be opposed.
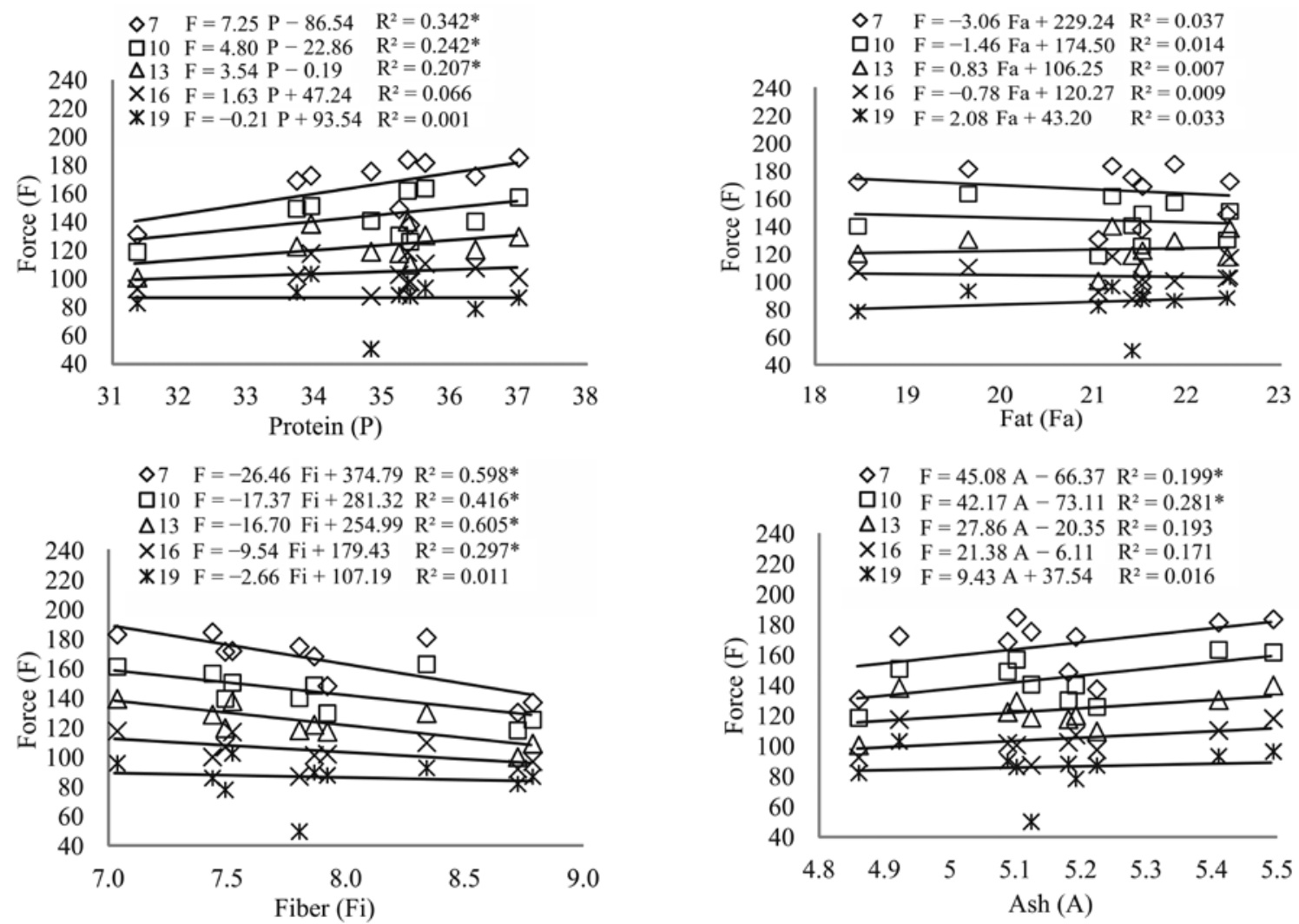

* - significant at $\alpha=0.05$

Figure 5. The relationship between destructive force $(\mathrm{N})$ and chemical composition of soybean seeds (\%) for five moisture contents $(7,10,13,16$ and $19 \%)$ 

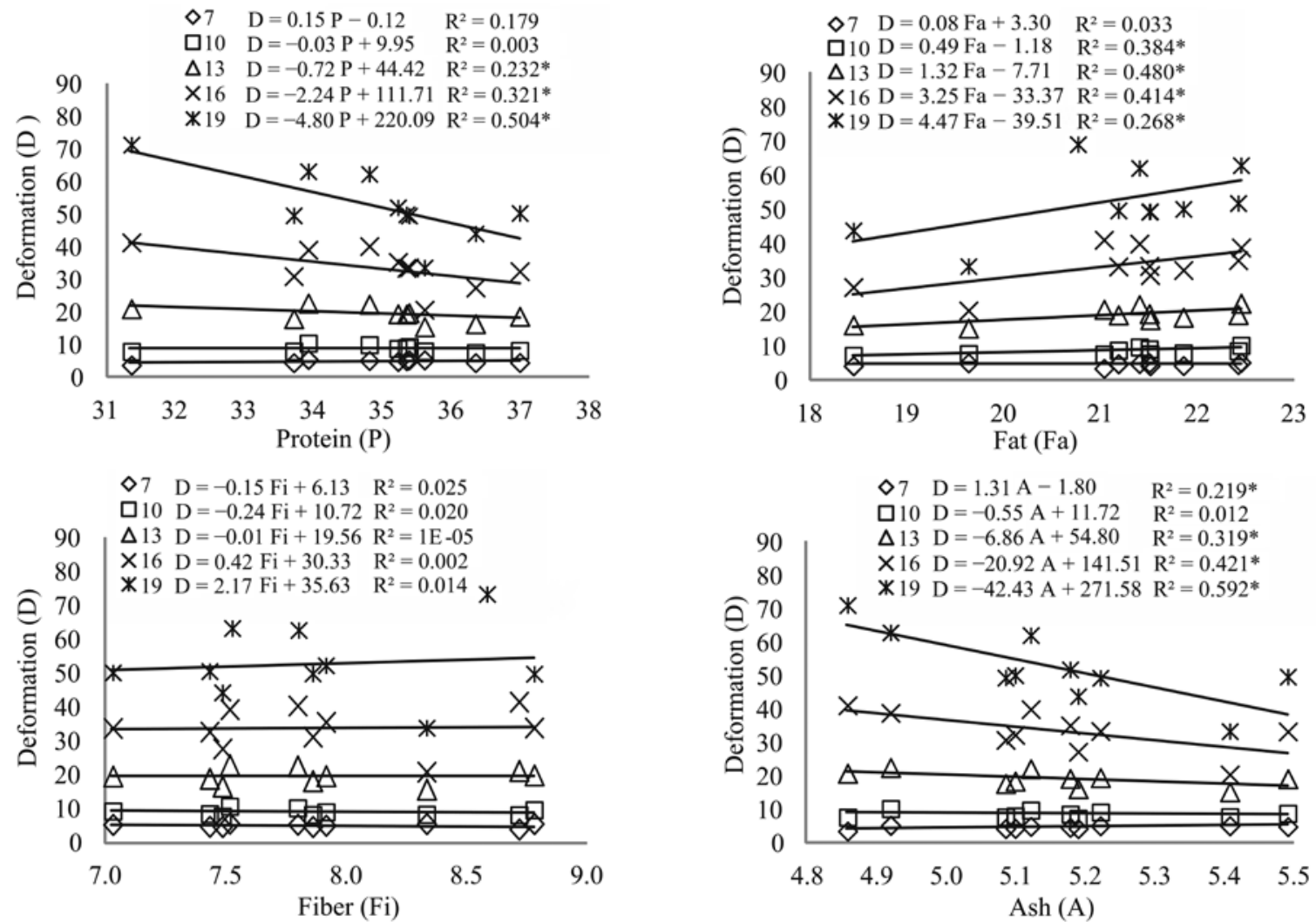

* - significant at $\alpha=0.05$

Figure 6. The relationship between deformation (\%) and chemical composition of soybean seeds (\%) for five moisture contents $(7,10,13,16$ and $19 \%)$
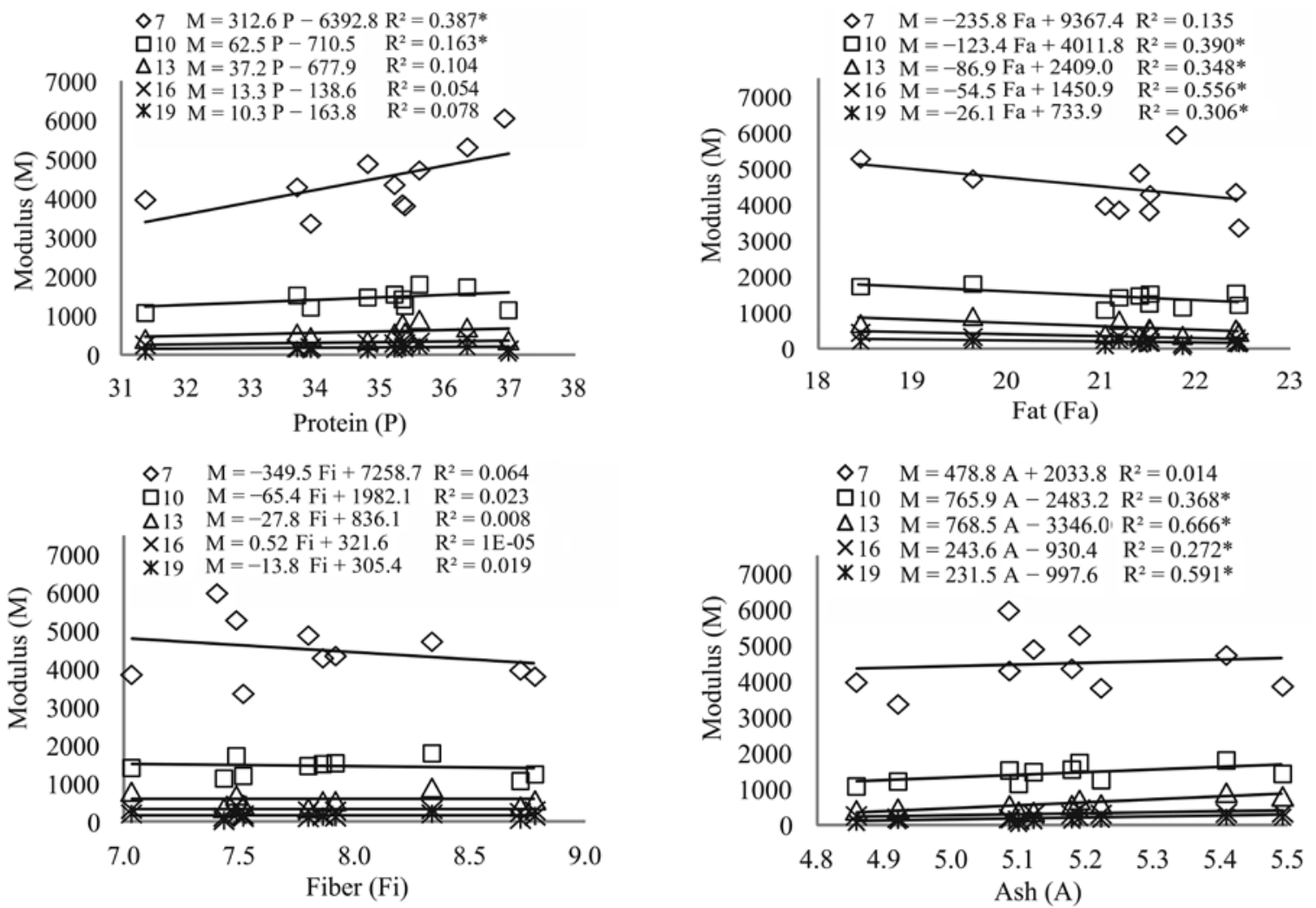

* - significant at $\alpha=0.05$

Figure 7. The relationship between modulus of elasticity (MPa) and chemical composition of soybean seeds (\%) for five moisture contents $(7,10,13,16$ and $19 \%)$ 

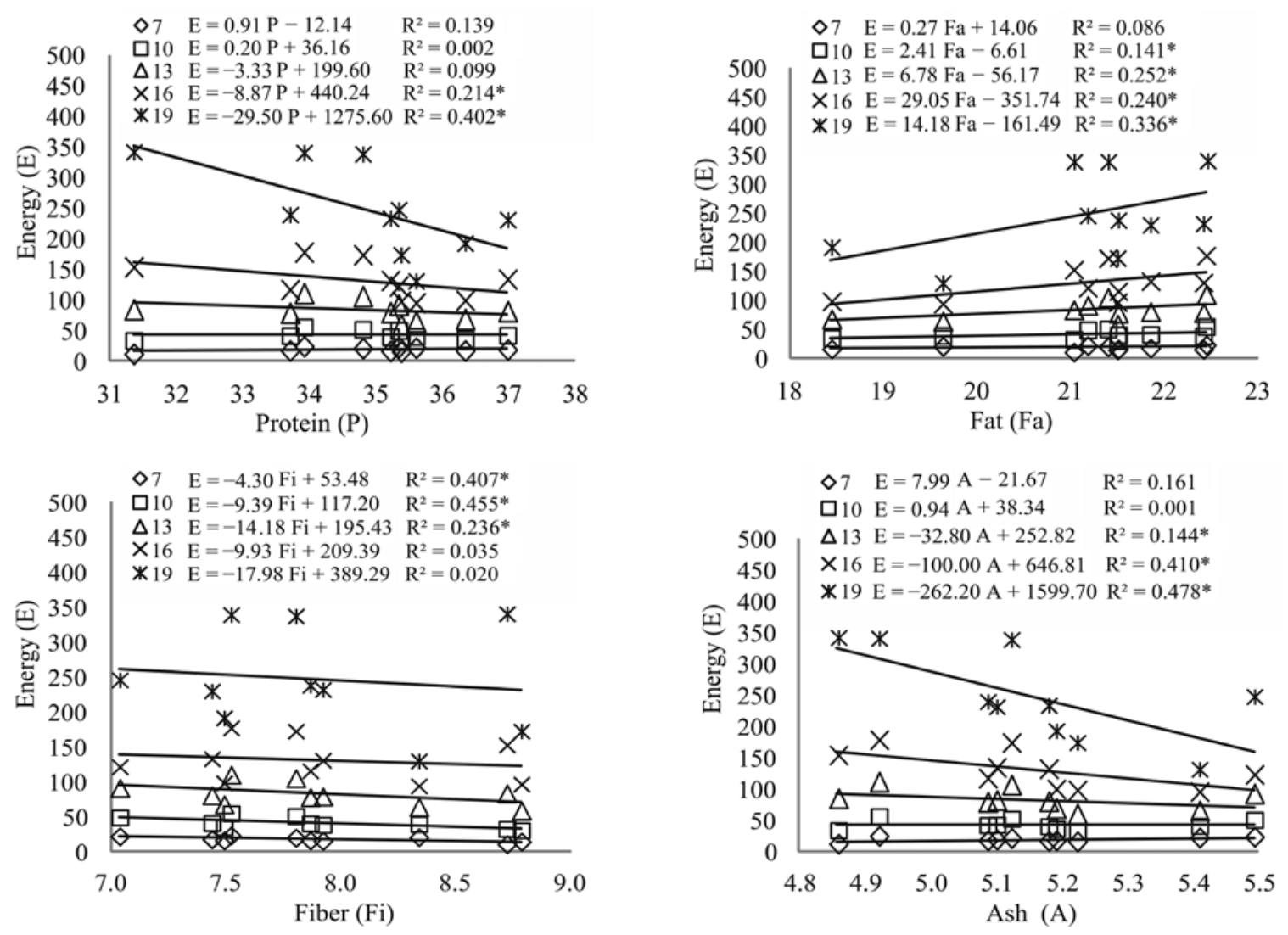

* - significant at $\alpha=0.05$

Figure 8. The relationship between destructive energy (mJ) and chemical composition of soybean seeds (\%) for five moisture contents $(7,10,13,16$ and $19 \%)$

\section{Conclusions}

1. The seeds of the examined cultivars of soybean are characterized by varied chemical and mechanical properties.

2. The seeds of 'Herta PZO' were significantly the most prone to deformation and damage at the application of minimum force. The seeds of cv. KS-40 significantly deformed the least and burst when the lowest amount of energy was used. The 'Petrina' was found to be significantly the least prone to damage and was also characterized by the highest destructive force parameter. The significantly highest seeming modulus of elasticity was observed for the seeds of cv. SP-16 and the highest energy for the 'Aligator'.

3. The increase of seed moisture content from $7 \%$ to $19 \%$ resulted in a significant decrease of destructive force and modulus of elasticity and an increase of deformation and rupture energy.

4. The soy cultivars significantly differed in terms of the average fat, fibre, and ash content in seed.

5. The impact of chemical composition of soybean seeds on their mechanical properties depended on their moisture content.

6. Soybean seeds with higher protein and ash content burst with the application of significantly higher amounts of force and were characterized by significantly higher modulus and less deformation and energy, and were therefore more resistant to damage. Soybean seeds containing more fat and fibre were significantly more prone to damage.

7. The increase of seed moisture content from $7 \%$ to $19 \%$ co-occurred with a significant decrease in the influence of the analyzed chemical composition on destructive force and modulus as well as an increase in deformation and energy.

Received 09112015

Accepted 19042016

\section{References}

Aghkhani M. H., Miraei Ashtiani S. H., Baradaran Motie J., Abbaspour-Fard M. H. 2012. Physical properties of Christmas Lima bean at different moisture content. International Agrophysics, 26 (4): 341-346 http://dx.doi.org/10.2478/v10247-012-0048-0

Altuntas E., Yildız M. 2007. Effect of moisture content on some physical and mechanical properties of faba bean (Vicia faba L.) grains. Journal of Food Engineering, 78: 174-183 http://dx.doi.org/10.1016/j.jfoodeng.2005.09.013

ASAE standard S352.2. 2006. Moisture measurement ungrounded grains and seeds

Capeleti I., Bonini E. A., Ferrarese M. L. L., Teixeira A. C. N., Krzyzanowski F. C., Ferrarese-Filho O. 2005. Lignin content and peroxidase activity in soybean seed coat susceptible and resistant to mechanical damage. Acta 
Physiologiae Plantarum, 27 (1): 103-108

http://dx.doi.org/10.1007/s11738-005-0042-2

Chigarev O. 2013. Mathematical model describing the process of crushing separate grain in an Instron strength testing machine. Problemy Inżynierii Rolniczej, 1 (79): 143-149 (in Polish)

Davies R. M., Zibokere D. S. 2011. Effect of moisture content on some physical and mechanical properties of three varieties of cowpea (Vigna unguiculata (L) Walp). Agricultural Engineering International: The CIGR Journal, 13 (1): 1-8

Divsalar M., Oskouei B. 2011. Study the effect of mechanical damage at processing on soybean seed germination and vigor. ARPN Journal of Agricultural and Biological Science, 6 (7): 60-64

Dobrzański B., Stępniewski A. 2013. Physical properties of seeds in technological processes. Grundas S., Stepniewski A. (eds.). Advances in Agrophysical Research, p. 269-294 http://dx.doi.org/10.5772/3341

Hebda T., Frączek J. 2005. Effect of selected factors on seed elasticity index. Inżynieria Rolnicza, 11 (71): 171-180 (in Polish)

Kabutey A., Herák D., Dajbych O., Divišová M., Boatri W. E., Sigalingging R. 2014. Deformation energy of Jatropha curcas L. seeds under compression loading. Research in Agricultural Engineering, 60 (2): 68-74

Karaj S., Müller J. 2010. Determination of physical, mechanical and chemical properties of seeds and kernels of Jatropha curcas L. Industrial Crops and Products, 32: 129-138 http://dx.doi.org/10.1016/j.indcrop.2010.04.001

Kiani Deh Kiani M., Minaei S., Maghsoudi H., Ghasemi Varnamkhasti M. 2008. Moisture dependent physical properties of red bean (Phaseolus vulgaris L.) grains. International Agrophysics, 22: 231-237

Kibar H., Öztürk T. 2008. Physical and mechanical properties of soybean. International Agrophysics, 22: 239-244

Koocheki A., Razavi S. M. A., Milani E., Moghadan T. M., Abedini M., Alamatiyan S., Izadikhah D. 2007. Physical properties of watermelon seed as a function of moisture content and variety. International Agrophysics, 21: $349-359$

Kumar V., Rani A., Solanki S., Hussain S. M. 2006. Influence of growing environment on the biochemical composition and physical characteristics of soybean seed. Journal of Food Composition and Analysis, 19: 188-195 http://dx.doi.org/10.1016/j.jfca.2005.06.005

Kuźniar P., Jarecki W., Bobrecka-Jamro D. 2013. Mechanical properties of the selected legume seeds and their weight and thickness. Inżynieria Rolnicza, 4 (147): 171-177 (in Polish)

Łysiak G., Laskowski J. 2007. The influence of wheat grain moisture on deformation during compression. Inżynieria Rolnicza, 5 (93): 279-284 (in Polish)

Milani E., Razavi S. M. A., Koocheki A., Nikzadeh V., Vahedi N., Moeenfard M., Gholamhosseinpour A. 2007. Moisture dependent physical properties of cucurbit seeds. International Agrophysics, 21 (2): 157-168

Moïse J. A., Han S., Gudynaite-Savitch L., Johnson D. A., Miki B. L. A. 2005. Seed coats: structure, development, composition, and biotechnology. In Vitro Cellular and Developmental Biology - Plant, 41 (5): 620-644 http://dx.doi.org/10.1079/IVP2005686
NasirahmadiA.,Abbaspour-Fard M.H., Emadi B., Khazaei N. B. 2014. Modelling and analysis of compressive strength properties of parboiled paddy and milled rice. International Agrophysics, 28: 73-83

Razari M. A., Emadzadeh B., Rafe A., Mohammed A. A. 2007. Physical properties of pistachio nut and its kernel as a function of moisture content and variety. Geometric properties. Journal of Food Engineering, 81: 209-217 http://dx.doi.org/10.1016/j.jfoodeng.2006.11.003

Rybiński W., Szot B., Rusinek R., Bocianowski J. 2009. Estimation of geometric and mechanical properties of seeds of Polish cultivars and lines representing selected species of pulse crops. International Agrophysics, 23: 257-267

Rybiński W., Starzycki M., Rusinek R., Bocianowski J., Szot B. 2013. Variation of legume seed's chemical composition and resistance to mechanical damage. Biuletyn Instytutu Hodowli i Aklimatyzacji Roślin, 268: 193-209 (in Polish)

Shahbazi F., Saffar A., Analooei M. 2011 (a). Mechanical damage to navy beans as affected by moisture content, impact velocity and seed orientation. Quality Assurance and Safety of Crops and Foods, 3: 205-211 http://dx.doi.org/10.1111/j.1757-837X.2011.00114.x

Shahbazi F., Saffar A., Analooei M. 2011 (b). Mechanical damage to pinto beans as affected by moisture content and impact energy. Agricultural Engineering International: CIGR Journal, 13 (2): 1-8

Shao S., Meyer C. J., Ma F., Peterson C. A., Bernards M. A. 2007. The outermost cuticle of soybean seeds: chemical composition and function during imbibition. Journal of Experimental Botany, 58 (5): 1071-1082 http://dx.doi.org/10.1093/jxb/erl268

Sharma V., Das L., Prandhan R. C., Naik N. S., Bhatnagar N., Kurell R. S. 2011. Physical properties of tung seed: an industrial oil yielding crop. Industrial Crops and Products, 33: $440-444$ http://dx.doi.org/10.1016/j.indcrop.2010.10.031

Sosnowski S., Kuźniar P. 1999. Effect of dynamic loading on the quality of soybean. International Agrophysics, 13: $125-132$

Szwed G., Łukaszuk J., 2007. Effect of rapeseed and wheat kernel moisture on impact damage. International Agrophysics, 21: 299-304

Tavakoli H., Rajabipour A., Mohtasebi S. S. 2009. Moisturedependent some engineering properties of soybean grains. Agricultural Engineering International: The CIGR Journal, XI: $1-14$ 
ISSN 1392-3196 / e-ISSN 2335-8947

Zemdirbyste-Agriculture, vol. 103, No. 2 (2016), p. 183-192

DOI $10.13080 /$ z-a.2016.103.024

\title{
Sojų sẻklų fizikinės ir cheminės savybès lemia jų jautrumą mechaniniams pažeidimams
}

\author{
P. Kuźniar ${ }^{1}$, E. Szpunar-Krok ${ }^{1}$, P. Findura² ${ }^{2}$ J. Buczek ${ }^{1}$, D. Bobrecka-Jamro' ${ }^{1}$ \\ ${ }^{1}$ Rzeszow universitetas, Lenkija \\ ${ }^{2}$ Nitros žemès ūkio universitetas, Slovakija
}

\section{Santrauka}

Tirta sojų pasirinktų veislių sėklų cheminės sudėties ir drègnio įtaka jų mechaninėms savybėms. Penkių drègnio lygių sėklos buvo tirtos kvazistatinių apkrovų sąlygomis, naudojant universalų testavimo prietaisą „Zwick“. Sojų sėklų mechaninès savybės priklausė nuo veislès, sėklų cheminès sudèties ir drègnio. Veislès 'Herta PZO' sèklos plyšdavo, kai buvo naudojama žymiai mažesnè plyšimo jègos galia $(105,6 \mathrm{~N})$ ir labiausiai deformavosi $(29,2 \%)$. Veislès KS-40 sèklos buvo linkusios žymiai mažiau deformuotis $(16,7$ \%) ir plyšo taikant mažiausią energijos kieki (71,5 mJ). Veislès 'Petrina' sèkloms plyšti reikèjo esmingai didžiausio jègos kiekio (140,6 N), o esmingai didžiausias elastingumo modulis (1721 MPa) buvo nustatytas veislès SP-16 sèkloms. Veislès 'Aligator' sèkloms plyšti reikèjo esmingai didžiausio energijos kiekio (142,7 mJ). Didèjant sẻklų drėgnio kiekiui, mažèjo plyšimo jègos kiekis bei modulis ir didejjo deformacija bei energija. Sojų sẻklos su didesniu kiekiu baltymų ir pelenų plyšo, kai buvo naudojama didesnè plyšimo jèga ir pasižymėjo didesniu elastingumo moduliu, mažesne deformacija bei energija ir todèl buvo atsparesnès mechaniniams pažeidimams. Sojų sẻklos, turinčios daugiau riebalų ir ląstelienos, buvo pažeidžiamiausios. Didejjant sėklų drėgniui (7-19\%) nustatytas tirtų cheminių komponentų įtakos mažėjimas plyšimo jègos kiekiui ir elastingumo moduliui. Kartu nustatytas tirtų komponentų įtakos padidejjimas deformacijai ir energijos kiekiui.

Reikšminiai žodžiai: cheminè sudètis, drègnio kiekis, mechaninės savybės.

Please use the following format when citing the article:

P. Kuzniar, E. Szpunar-Krok, P. Findura, J. Buczek, D. Bobrecka-Jamro. 2016. Physical and chemical properties of soybean seeds determine their susceptibility to mechanical damage. Zemdirbyste-Agriculture, 103 (2): 183-192 DOI 10.13080/z-a.2016.103.024 